\title{
Nearly Zero Energy Standard for Non-Residential Buildings with high Energy Demands-An Empirical Case Study Using the State-Related Properties of BAVARIA
}

\author{
Michael Keltsch ${ }^{1, *}$, Werner Lang ${ }^{1}$ and Thomas Auer ${ }^{2}$ \\ 1 Institute of Energy Efficient and Sustainable Design and Building, Technical University of Munich, \\ Arcisstraße 21, 80333 Munich, Germany; jutta.bergmann@tum.de \\ 2 Chair of Building Technology and Climate Responsive Design, Technical University of Munich, \\ Arcisstraße 21, 80333 Munich, Germany; klima@lrz.tum.de \\ * Correspondence: michael.keltsch@tum.de; Tel.: +49-89-289-23990
}

Academic Editor: Francesco Guarino

Received: 3 January 2017; Accepted: 10 March 2017; Published: 15 March 2017

\begin{abstract}
The Energy Performance of Buildings Directive (EPBD) 2010 calls for the Nearly Zero Energy Building (nZEB) Standard for new buildings from 2021 onwards: Buildings using "almost no energy" are powered by renewable sources or by the energy produced by the building itself. For residential buildings, this ambitious new standard has already been reached. But for other building types, this goal is still far away. The potential of these buildings to meet a nZEB Standard was investigated by analyzing ten case studies, representing non-residential buildings with different uses. The analysis shows that the primary characteristics common to critical building types are a dense building context with a very high degree of technical installation (such as hospital, research, and laboratory buildings). The large primary energy demand of these types of buildings cannot be compensated by building- and property-related energy generation, including off-site renewables. If the future nZEB Standard were to be defined with lower requirements because of this, the state-related properties of Bavaria suggest that the real potential energy savings available in at least $85 \%$ of all new buildings would be insufficiently exploited. Therefore, it would be more useful to individualize the legal energy verification process for new buildings, to distinguish critical building types such as laboratories and hospitals from the other building types.
\end{abstract}

Keywords: Energy Performance of Buildings Directive (EPBD 2010); Nearly Zero Energy Building (nZEB) Standard; non-residential buildings; highly technically installed buildings; energy balance

\section{Introduction}

Effectively reducing the energy consumption in the building sector and using renewable energies are central components of the implementation of the Paris Convention on Climate Change Agreements of December 2015. The building sector is responsible for about $40 \%$ of the total energy consumption of the EU and EU forecasts predict further expansion [1] (L153/13). Therefore, in 2010, the European Union replaced the first EPBD adopted in 2002, calling upon Member States to implement the jointly formulated objectives. The directive extensively applies to the building stock. It establishes the minimum required standards for renovating existing buildings and replacing individual building components.

From 2021, the nZEB Standard will be required for all new buildings. From then onwards, all new buildings must guarantee "a very high energy performance (...). The nearly zero or very low amount of energy required should be covered to a very significant extent by energy from renewable sources, 
including energy from renewable sources produced on-site or nearby." It is the responsibility of each member country to establish an exact definition for this standard within the framework of the European Directive [1] (Art. 2 No. 2).

For residential buildings, fulfilling these requirements is already possible. Passive Houses and even Net Zero Energy Buildings have already been implemented and tested [2,3]. As the residential building sector dominates construction activity in Germany (40.6\% in 2014 [4]), many studies on future building standards have primarily focused on residential buildings [5,6]. But what about large infrastructure projects, e.g., new hospitals, institute buildings, or research laboratories? These buildings only make up a small part of the annual construction volume, but they consume significantly more energy than other types of buildings. Figure 1 shows the share of the six most important sectors of new construction activity in 2014 [4]. For each sector, the final energy demand of the energy saving regulations Energieeinsparverordnung (EnEV) 2013 [7] reference buildings of selected usage zones, were determined and compared to the demand of a typical residential zone (blue areas). Most non-residential uses have a higher energy demand than that of housing. The selected infrastructure buildings (e.g., laboratory usage) were found to have an energy demand of approximately five times that of a housing zone (own simulation). In contrast, the average potential of renewable energies in residential buildings is sufficient to compensate the demand in the annual balance sheet (inner green sectors). Infrastructure buildings often have a lower potential because of their dense building context and higher energy demands (own qualitative estimation). For example, a residential building is currently able to compensate its specific energy demands of non-renewable primary energy ( $Q^{\prime}{ }_{\mathrm{PNE}} 100 \%$ - blue area) by the specific generation of renewable energies $\left(Q^{\prime}{ }_{\mathrm{RE}} 100 \%\right.$ - green frame) in a net balance over a year, even if it is a multi storey building [8]. Laboratory buildings or hospitals (special public infrastructure buildings) have up to five-times the specific energy demand of a residential building (blue area $\mathrm{Q}_{\mathrm{PNE}}^{\prime}=490 \%$ ). In addition, the potential of using renewable energies is regularly limited due to technical installations on the roof and also due to their peculiar built type (estimated green frame; e.g., $\mathrm{Q}_{\mathrm{RE}}^{\prime}=25 \%$ ).

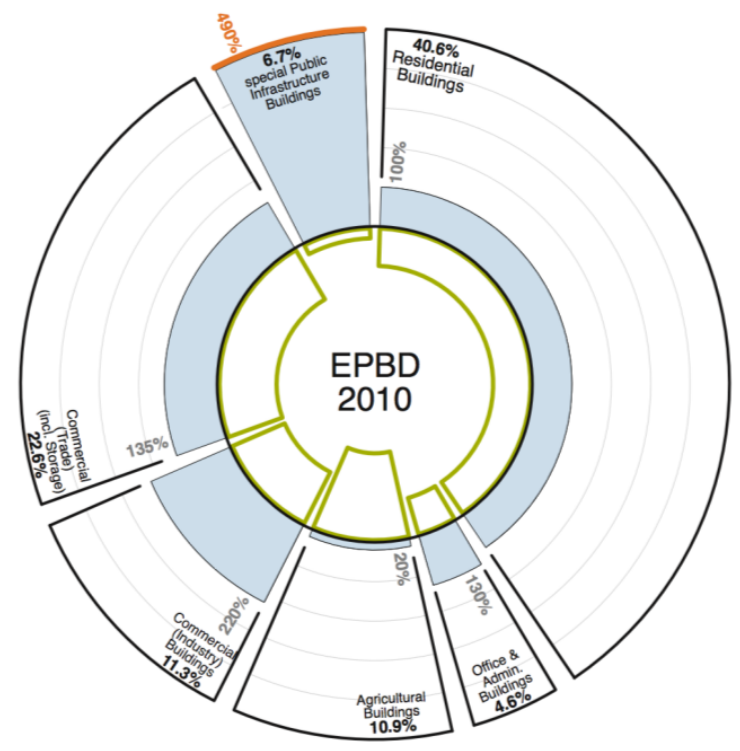

Figure 1. The new building volume in 2014 in Germany with the energy demand of each typical usage zone, as well as its potential for renewable energies (own representation according to [4]).

Will these critical building types be able to fulfil the requirements of the EPBD 2010 from 2021 onwards? Or-to account for these types of buildings-will the requirements be reduced for all building types to such an extent that much of the potential to reduce energy demands remains unused? 
This study investigates this question by considering the properties owned by the Free State of Bavaria, to which the regulations for normal temperature buildings stipulated by the EnEV 2013 apply.

Based on the average building parameters of each category of non-residential buildings, ten case studies were selected, and their potential as nZEB for 2021 was analyzed. These real buildings were surveyed for their geometry, components, and usage zoning, and were given a fictional building standard indexed to the year 2021. The calculations were carried out with the tool EnerCalC 2013 [6]. The results were discussed in the light of the objectives of the EPBD 2010 and possible requirements for new buildings from 2021 onwards.

Finally, the results of the case studies were applied to assess the risk of the properties owned by the State of Bavaria, with the aim of obtaining an estimate of how many new projects from 2021 onwards might have critical building types.

\section{Property Portfolio of the Free State of Bavaria}

The State of Bavaria has over 10,000 built-up properties in its permanent portfolio. The portfolio ranges from simple warehouses to high-tech surgery centers, and from prisons to buildings of the UNESCO World Cultural Heritage, which represent Bavaria's global image [9]. Nevertheless, the real estate portfolio of a state such as Bavaria is not typically representative of the building stock in Germany. Its composition instead reflects the history of the state and the tasks assigned to federal states within the Federal system of Germany. The portfolio includes building types that can only be found within states (for example police building and court houses). However, commercial buildings are not included. The percentage of housing and accommodation buildings is significantly smaller than the average German building stock. All of the building properties managed by the Bavarian Building Authority are grouped together in a central database (Fachdatenbank Hochbau, April 2015) [10]. The original data set contains 20,054 records of properties within Bavaria.

The data were filtered according to the following criteria: Property owned by the Free State of Bavaria, within the scope of the EnEV 2013, plausibility and completeness of the data, and buildings regulated to normal temperatures. After data preprocessing, 4401 records (buildings) were selected for the evaluation.

The Bauwerkzuordnungskatalog (BZK) of the Conference of Ministers of the States, responsible for urban development, construction, and housing, was used to classify the uses of these buildings. This catalogue defines building uses using a four-digit code, in which each digit represents a more detailed subdivision of building uses [11]. Only the first and second digits of this classification (depth of analysis) are largely relevant in the context of the energy analysis of non-residential buildings. Subdivisions beyond the second digit are no longer relevant for energy analysis, according to DIN V 18599 [12], since the energy demands of specific processes are not balanced [13].

The building stock of Bavaria (Figure 2) analyzed in this study consists of nearly one-third office and administrative buildings, including court and parliament buildings. This group also leads in terms of the gross floor area (GFA: 33.3\%) and the gross building volume (GBV: 31.0\%). Group 7000, buildings for production, storage, and maintenance, and group 6000, residential and housing buildings, represent a higher percentage of the total number of buildings, but a comparatively lower percentage of the total GFA and GBV. These building types are comparatively small-scale and small-volume. Buildings for science, teaching, and research, as well as for health, lie on the opposite end of the spectrum. They represent a very high percentage of the GFA and the GBV, relative to the number of buildings. These buildings are disproportionately large on average. The differences within group 4000, buildings for education and culture, in terms of numbers, GFA, and GBV, are similar to groups 2000 and 3000 , but are not so extreme.

In order to find suitable case studies for each type of building, the characteristics of GFA and the number of usable floors (UF) of each category were investigated. The average values of the GFA and UF of each main category (Figure 3) served as a guide for selecting the case studies. The spread in the average values of the subcategories is shown, together with their minimum and maximum values. 
Since the BZK [11] categories 5000, 8000, and 9000 tend to have small buildings with a low number of usable floors, and the category 6000 is already very well studied, this study concentrates on the categories 1000 to 4000 .

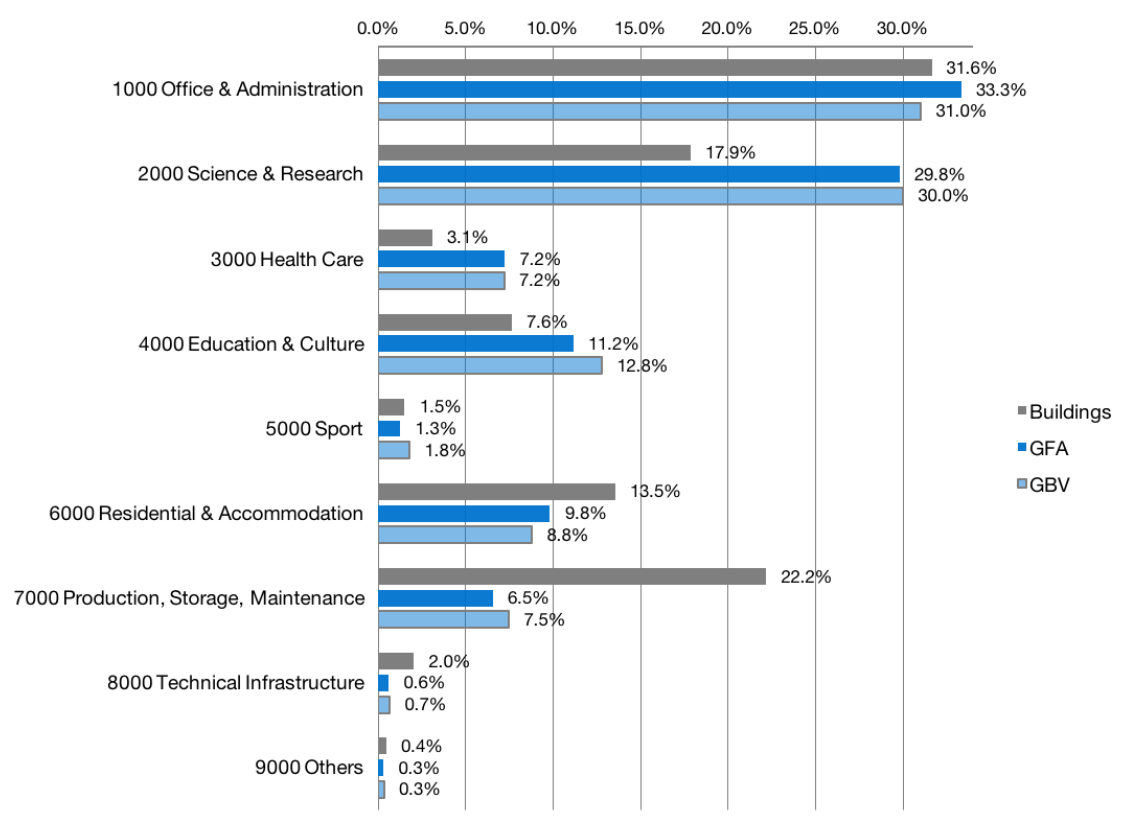

Figure 2. Percentage of building types among the building properties of the Free State of Bavaria, according to the first digit of their type in the Bauwerkzuordnungskatalog (BZK) (own representation according to [10]).

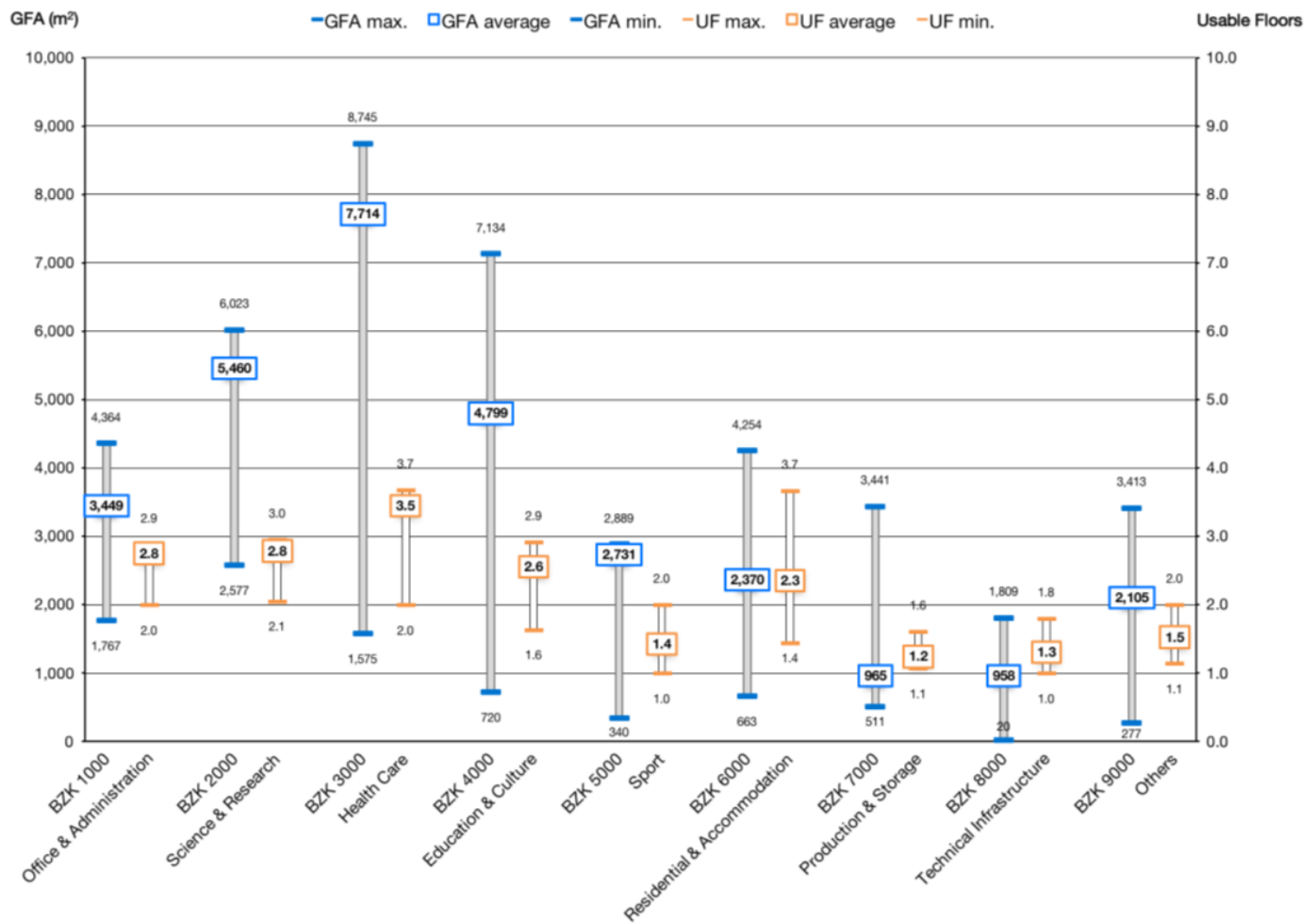

Figure 3. Empirical survey of the average values of the main categories (first digit) and spread in the subcategories (second digit), separated by gross floor area (GFA) and above-ground usable floors (UF) (own representation according to [10]). 


\section{Case Studies}

The case study buildings range from a two-storey administrative building with $1622 \mathrm{~m}^{2}$ GFA to a seven-storey research institute with $18,525 \mathrm{~m}^{2}$ GFA (Table 1). The cost group 4, according to DIN 276, is taken as an indicator of the technical installation level [14]. The percentage of the cost group 4 (KG 4: Building-technical installations without equipment of the user) is listed, relative to the overall construction costs (KG 3 and 4) $[15,16]$. The installation rates, as measured by these cost components, range from $24 \%$ (library with low air quality requirements) for the least installed buildings, to $52 \%$ (laboratory building) for the most highly installed buildings. The use of the building is indicated by the BZK [11]. The zoning according to DIN V 18599-10 [12] uses between four and 14 different zones (see Section 4). All of the case studies are based on buildings that are either under construction or less than eight years old. They were rated within the energy requirements using the calculation method of the DIN V 18599 [12] with different usage zones. The different construction years of the buildings are not relevant for the investigation results, due to the uniform recalculation of the energetic performance of RB and nZEB (see Section 5).

The case studies were incrementally selected. When a building fulfilled the expectations of the nZEB Standard, a building with a larger floor area, higher floor number, and higher percentage of KG4/BWK was then examined. Therefore, the projects under investigation tend to be in the upper part of the categories shown in Figure 3, or even above them. The choice of buildings was limited by the number of available data of case studies.

Table 1. Overview of the case studies with the categories code by Bauwerkzuordnungskatalog (BZK; this catalogue defines building uses using a four-digit code [11]), building use, number of usable floors (UF), gross floor area (GFA), gross building volume (GBV), the ratio of envelope area to volume $(\mathrm{A} / \mathrm{V})$, the percentage of window area to the envelope area, the percentage of the construction costs of technical installation to the overall construction costs (KG4/BWK), and the number of usage zones for energy performance calculations according to DIN V 18599-10 [12].

\begin{tabular}{|c|c|c|c|c|c|c|c|c|c|}
\hline $\begin{array}{l}\text { Case } \\
\text { Study }\end{array}$ & BZK & $\begin{array}{l}\text { Building } \\
\text { Use }\end{array}$ & $\begin{array}{l}\text { Usable } \\
\text { Floors }\end{array}$ & $\begin{array}{l}\text { GFA } \\
\left(\mathrm{m}^{2}\right)\end{array}$ & $\begin{array}{l}\text { GBV } \\
\left(\mathrm{m}^{3}\right)\end{array}$ & $\begin{array}{c}\mathrm{A} / \mathrm{V} \\
\left(\mathrm{m}^{-1}\right)\end{array}$ & $\begin{array}{c}\text { Percentage } \\
\text { Window Area }\end{array}$ & $\begin{array}{c}\text { Percentage } \\
\text { (KG4/BWK) }\end{array}$ & $\begin{array}{l}\text { Number of } \\
\text { Use Zones }\end{array}$ \\
\hline 01 & 1100 & $\begin{array}{l}\text { Parliament } \\
\text { Building }\end{array}$ & 7 & 5009 & 16,350 & 0.24 & $39 \%$ & $34 \%$ & 10 \\
\hline 02 & 1200 & Courthouse & 3 & 5392 & 19,944 & 0.36 & $35 \%$ & $30 \%$ & 6 \\
\hline 03 & 1340 & $\begin{array}{l}\text { Police } \\
\text { Station }\end{array}$ & 2.5 & 1622 & 5885 & 0.33 & $23 \%$ & $30 \%$ & 6 \\
\hline 04 & 2240 & $\begin{array}{l}\text { University } \\
\text { Institute }\end{array}$ & 4 & 5715 & 23,318 & 0.26 & $24 \%$ & $47 \%$ & 8 \\
\hline 05 & 2270 & $\begin{array}{l}\text { Research } \\
\text { Institute }\end{array}$ & 3 & 9978 & 45,185 & 0.30 & $43 \%$ & $35 \%$ & 9 \\
\hline 06 & 2320 & $\begin{array}{l}\text { Research } \\
\text { Centre }\end{array}$ & 6 & 18,525 & 74,947 & 0.18 & $62 \%$ & $50 \%$ & 4 \\
\hline 07 & 2500 & $\begin{array}{l}\text { Laboratory } \\
\text { Building }\end{array}$ & 4 & 5822 & 24,440 & 0.27 & $29 \%$ & $52 \%$ & 9 \\
\hline 08 & 3112 & $\begin{array}{l}\text { Hospital } \\
\text { Building }\end{array}$ & 5 & 9919 & 41,933 & 0.29 & $54 \%$ & $51 \%$ & 9 \\
\hline 09 & 4500 & Library & 4 & 1982 & 8429 & 0.51 & $22 \%$ & $24 \%$ & 7 \\
\hline 10 & 4620 & $\begin{array}{l}\text { Museum } \\
\text { Building }\end{array}$ & 3.5 & 10,900 & 79,399 & 0.26 & $12 \%$ & $37 \%$ & 14 \\
\hline
\end{tabular}

\section{Definition of a Nearly Zero Energy Standard}

Europe is divided into many different types of climate classes [17]. To take this into consideration, each Member State is able to find its own definition for nZEB within the EPBD framework. This investigation is limited to the climate class $\mathrm{Cfb}$, which is the reference climate for the EnEV balancing system in Germany and equals the climate class of Bavaria. 
This work is based on the goal of climate protection. The specific non-renewable primary energy demand $\left(\mathrm{Q}^{\prime} \mathrm{PNE}\right)$ is chosen as the main requirement of the analysis. $\mathrm{CO}_{2}$ emissions could have been one possible alternative. However, they are less present in the energy balancing of buildings and would only represent an alternative conversion of delivered energy demands. The EPBD 2010 provides a general framework for calculating the energy performance, setting clear guidelines that comply with the German balancing standards required by EnEV and DIN V 18599. It was therefore chosen as the calculation system for this study [1] (Annex I) [12]. Non-residential buildings are divided into different areas of use. Each usage zone has specific usage profiles and room conditions. The minimum level of energy performance is defined by the reference building (RB). The RB has the same zoning and geometry as the planned building, but it is equipped with a uniform building technology and a uniform quality of the building envelope that are standardized in the EnEV. The energy performance of the RB (according to EnEV 2013) for each case study differs, due to the individual usage zones and the different geometries of the buildings. The planned building has to have at least the same level of energy performance as its individual RB [7].

There are deviations from the above methodology in some respects. As in $[3,5,6]$, the self-production of energy is fully calculated if it can be provided to the grid. This corresponds to all of the current definitions of net zero energy and net plus energy buildings. In addition, the primary energy factors are not asymmetrically designed. This means that the same primary energy factor is applied to the grid feed and supply. Indicating a political preference by weighting with various factors is excluded in this investigation. Furthermore, only unique primary factors are used for the case studies, to avoid location-related advantages. Therefore, local and district heating from cogeneration always uses the same calculation factors. The overview of the definition framework (Table 2) is based on the systematics of [18].

Table 2. Overview of the Nearly Zero Energy Standard definition framework.

\begin{tabular}{cl}
\hline \multicolumn{1}{c}{ Criteria } & \multicolumn{1}{c}{ Definition } \\
\hline Physical Boundary & Building site (including auxiliary buildings) \\
\hline Balance Boundary & $\begin{array}{l}\text { All energies according to the building operation } \\
\text { (EPBD: heating, cooling, ventilation, domestic hot water, lightning, } \\
\text { auxiliary power) }\end{array}$ \\
\hline Renewable Energy Supply & $\begin{array}{l}\text { On-Site generation from on-site renewables (sun, wind, ... ) and } \\
\text { off-site renewables (transportation of sources needed, biomass, ... ) } \\
\text { Class III by [19,20] }\end{array}$ \\
\hline Boundary Conditions & Usage profiles according to DIN V 18599-10 \\
\hline Weighting System & $\begin{array}{l}\text { Primary energy demand (non-renewable) } \\
\text { with symmetrical weighting of the conversion factors }\end{array}$ \\
\hline Balancing Period & Calendar year (with monthly balancing) \\
\hline Type of Balance & Input-Output-Balance \\
\hline
\end{tabular}

The EPBD 2010 (Annex I) calls for the total energy efficiency and primary energy consumption to be transparently represented. The calculation according to EnEV always outputs only one value per requirement category. Laypersons may find it difficult to understand how this value is composed. The system of net accounting uses a representation based on the demand (input) and the production (output) of energy [3]. This survey provides an easy-to-understand and transparent description of the performance of a building (Figure 4).

The reference value is always the $\mathrm{Q}^{\prime} \mathrm{PNE}$ of the reference building, according to EnEV (100\%). The value $Q^{\prime}{ }^{\prime}{ }^{\prime}$ re represents the percentage variation in primary energy use and is an indicator of the overall efficiency of the building operation. This value is reduced by increasing the building's self-consumption of renewable energies (lower input value on the x-axis). The output (y-value) is 
increased by increasing the energy supplied to the grid. If the output exceeds the value of the input (angle bisector), then the building meets the net zero energy standard. Since meeting this standard is not required for nZEB, a lower degree of coverage (allowing the energy demand to be compensated by grid feed) could provide a definition for nZEB. The purpose of the case studies is to analyze this option.

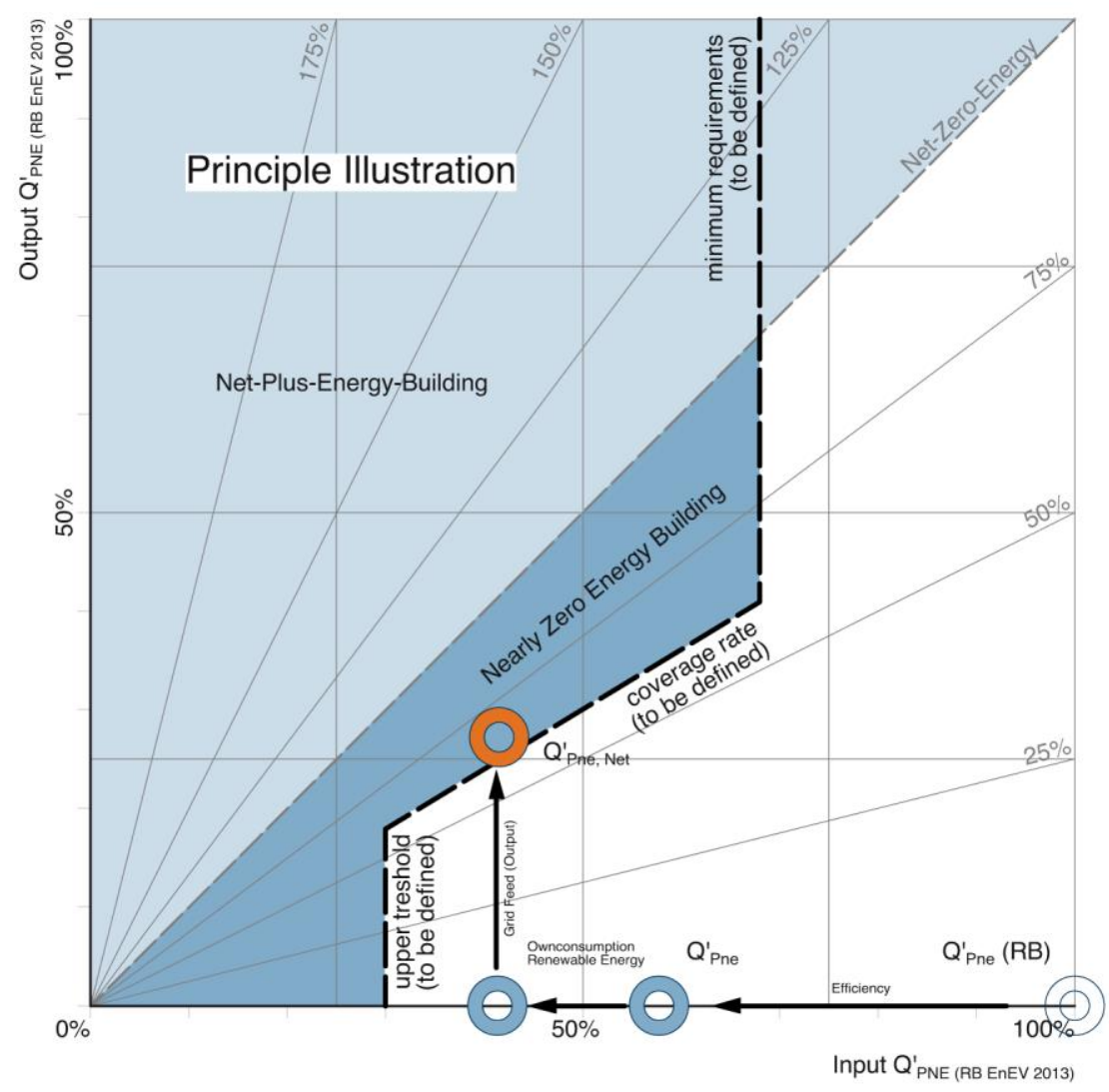

Figure 4. Illustration of the principle for the Nearly Zero Energy Standard based on the representation of an input-output balance (own representation according to [3]); The presentation is a specific requirement relative to the reference building (RB according to EnEV 2013).

An upper limit for the inputs of new buildings must be chosen in order to define the minimum standards for energy efficiency that take into account the buildings' consumption of the renewable energy produced by their own systems. A high threshold for energy efficiency (Figure 4 dashed line), above which no feed-in is necessary, should also be discussed for buildings that do not have the possibility to generate energy on-site (for example dense, shaded city centers).

\section{Analysis Method}

\subsection{Tool EnerCalC}

It is doubtful that the existing EnEV balance sheets of the case studies are comparable. They were developed by different creators using different software with very different approaches. An evaluation of different commercial software, for the same building, shows considerable differences in the calculation results [21]. A new unique recalculation following a unique framework is necessary, in order to be able to make comparable qualitative statements in the analysis of the case studies.

The calculation tool EnerCalC 2013 is therefore used. EnerCalC 2013 uses the accounting method of DIN V 18599, including the differentiation of usage zones for non-residential buildings. It is designed to simplify the extremely complex surface area of zones and the associated thermal heat transfer surfaces, without having to dispense with the advantages of multi-zone models [22,23]. 
EnerCalC was compared to commercially available software before the study for three of the case studies. This comparison found an average deviation of 3.3\%, and a maximum deviation of $7.9 \%$. For the qualitative assessment, it is important to analyze all of the considered case studies using the same tool.

\subsection{Assumed Nearly Zero Energy Standard 2021 (nZEB 2021)}

Buildings can no longer be considered as isolated systems. The study [24] considers two main characteristics that directly relate to new buildings in the future, taking into account the conversion of the energy production and network infrastructure:

- Reduction of energy demands by consistently exploiting all efficiency potentials,

- Change of heat supply: away from chemically bound energy to electrically operated heat pumps (primarily geothermal heat pumps).

Against this background, a future building standard is indicated for 2021 and the climatic conditions of Bavaria (Table 3), and is then applied to the real case studies for analysis. Passive measures for reducing the demand are preferable to active efficiency measures [25]. An accepted standard for 2021 cannot replace individual building planning and should only make a qualitative statement.

Without a considerable advance in technology, no heat transfer coefficient (U-value) below 0.08 to $0.1 \mathrm{~W} / \mathrm{m}^{2} \mathrm{~K}$ will become commercially viable for outdoor components in the foreseeable future [26]. This would not make sense given our commercially available insulation materials when taking a holistic view of the life cycle. The energy required to produce large quantities of insulation with a U-value of e.g., $0.15 \mathrm{~W} / \mathrm{m}^{2} \mathrm{~K}$ to $0.1 \mathrm{~W} / \mathrm{m}^{2} \mathrm{~K}$, would no longer be beneficial, relative to the energy saved during the operation of the building [27]. For transparent parts of the building envelope, triple-glazed glazing is customary. High-quality window constructions already achieve $U_{\mathrm{W}}$-values of $0.70 \mathrm{~W} / \mathrm{m}^{2} \mathrm{~K}$. To simplify the analysis, the window geometries were not individually recalculated. The $\mathrm{U}_{\mathrm{W}^{-}}$and the g-value were assumed to be uniform for all sizes of windows and all orientations.

The technical conditioning of the usage zones was taken from the actual execution of the case studies. For the technical systems, a highly efficient state-of-the-art building standard was chosen.

The electrically operated geothermal heat pump was selected due to the reasons mentioned above, and was associated with an evaporation of all market-based heaters, relative to their primary energy requirements and their availability at all locations. The available roof area (class 1, according to [28]) for solar energy use ( $\mathrm{A}_{\mathrm{SEU}}$ ) was empirically determined by the roof planning of the case studies. The area was provided for radiation energy use, including a deduction for maintenance areas (Table 3).

Table 3. Areas of solar energy use on the roofs of the case studies-total roof area $\left(\mathrm{A}_{\text {Roof }}\right)$, empirically measured available roof area for solar energy use (ASEU), balanced footprint area for solar collectors $\left(\mathrm{A}_{\mathrm{SH}}\right)$ for heat support and drinking hot water, and area for photovoltaics $\left(\mathrm{A}_{\mathrm{PV}}\right)$; each area is in square meters and the percentage of the total roof area.

\begin{tabular}{|c|c|c|c|c|c|c|c|c|c|}
\hline Case Study & BZK & Building Use & $\begin{array}{c}A_{\text {Roof }} \\
\left(\mathrm{m}^{2}\right)\end{array}$ & $\begin{array}{c}A_{\text {SEU }} \\
\left(\mathrm{m}^{2}\right)\end{array}$ & $\begin{array}{c}\mathbf{A}_{\text {SEU }} \\
(\%)\end{array}$ & $\begin{array}{l}A_{S H} \\
\left(m^{2}\right)\end{array}$ & $\begin{array}{c}A_{\text {SH }} \\
(\%)\end{array}$ & $\begin{array}{l}A_{P V} \\
\left(m^{2}\right)\end{array}$ & $\begin{array}{l}A_{P V} \\
(\%)\end{array}$ \\
\hline 01 & 1100 & Parliament Building & 629 & 321 & $51 \%$ & 61 & $10 \%$ & 260 & $41 \%$ \\
\hline 02 & 1200 & Courthouse & 1957 & 1198 & $61 \%$ & 98 & $5 \%$ & 1100 & $56 \%$ \\
\hline 03 & 1340 & Police Station & 613 & 513 & $84 \%$ & 33 & $5 \%$ & 480 & $78 \%$ \\
\hline 04 & 2240 & University Institute & 1398 & 983 & $70 \%$ & 73 & $5 \%$ & 910 & $65 \%$ \\
\hline 05 & 2270 & Research Institute & 2898 & 2100 & $72 \%$ & 170 & $6 \%$ & 1930 & $67 \%$ \\
\hline 06 & 2320 & Research Centre & 3322 & 1202 & $36 \%$ & 252 & $8 \%$ & 950 & $29 \%$ \\
\hline 07 & 2500 & Laboratory Building & 968 & 640 & $66 \%$ & 90 & $9 \%$ & 550 & $57 \%$ \\
\hline 08 & 3112 & Hospital Building & 2478 & 826 & $33 \%$ & 376 & $15 \%$ & 450 & $18 \%$ \\
\hline 09 & 4500 & Library & 444 & 310 & $70 \%$ & 0 & $0 \%$ & 310 & $70 \%$ \\
\hline 10 & 4620 & Museum Building & 3263 & 2552 & $78 \%$ & 172 & $5 \%$ & 2,380 & $73 \%$ \\
\hline
\end{tabular}


An approach using a unique percentage of the whole roof area for solar use would ignore the fact that different types of non-residential buildings have a typical amount of technical roof installations that reduces the potential of solar use of the building. Solar energy use on the roofs of auxiliary buildings is excluded. However, Case Study 03 (police station) is an exception. In this case, the auxiliary building (car parking and maintenance) is a part of the standard program of this building type. The details of the assumed nZEB Standard can be found in Table 4.

Table 4. Assumed Nearly Zero Energy Standard for 2021 (for climate class Cfb according to [17]).

\begin{tabular}{|c|c|c|c|}
\hline & Component/System & Attribute & $\begin{array}{c}\text { Definition for assumed Nearly Zero Energy } \\
\text { Standard } 2021\end{array}$ \\
\hline \multirow{5}{*}{ 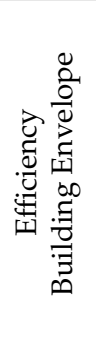 } & Opaque envelope comp. & U-Value & $0.15 \mathrm{~W} /\left(\mathrm{m}^{2} \mathrm{~K}\right)$ \\
\hline & $\begin{array}{l}\text { Transparent envelope } \\
\text { components }\end{array}$ & U-Value & $\begin{aligned} 0.70 \mathrm{~W} /\left(\mathrm{m}^{2} \mathrm{~K}\right) & \text { with } \mathrm{U}_{\mathrm{g}}=0.5 \mathrm{~W} /\left(\mathrm{m}^{2} \mathrm{~K}\right) \\
\mathrm{U}_{\mathrm{f}} & =0.7 \mathrm{~W} /\left(\mathrm{m}^{2} \mathrm{~K}\right) \\
\Psi & =0.045 \mathrm{~W} / \mathrm{mK}\end{aligned}$ \\
\hline & & g-Value & 0.50 \\
\hline & Heat bridging coefficient & $\Delta \mathrm{UWB}$ & $0.01 \mathrm{~W} /\left(\mathrm{m}^{2} \mathrm{~K}\right)$ \\
\hline & Building impermeability & n50/q50 & $0.61 / \mathrm{h}$ \\
\hline \multirow{8}{*}{ 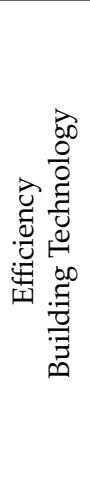 } & Lighting & Techn. System & Self-ballasted fluorescent tube light \\
\hline & Lighting control & Techn. System & $\begin{array}{l}\text { Often presence detector } \\
\text { \& constant lighting settings } \\
\text { sometimes zone-dependent }\end{array}$ \\
\hline & Ventilation & Techn. System & As case study \\
\hline & Recovery coefficient & $\eta \mathrm{t}$ & 0.75 \\
\hline & Cooling & Techn. System & As case study \\
\hline & Coolers & Techn. System & Water cooled compressor (efficient) \\
\hline & Cold transfer & Techn. System & Large area components \\
\hline & Heat transfer & Techn. System & Large area components, PI-Regulation \\
\hline \multirow{4}{*}{ 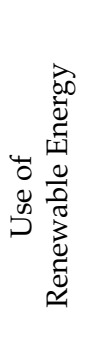 } & Heating & Techn. System & Brine/water heat pump (DIN V 18599-5) \\
\hline & $\begin{array}{l}\text { Roof Area for Solar } \\
\text { Energy Use (ASEU) }\end{array}$ & Area & $\begin{array}{l}\text { Empirically measured area (potential class } 1 \text { [28]) } \\
\text { of case studies minus maintenance area }\end{array}$ \\
\hline & Solar heating & Techn. System & $\begin{array}{l}\text { Flat collectors; size of the footprint of the } \\
\text { collector area }\left(\mathrm{A}_{\mathrm{SH}}\right) \text { optimized by calculation for } \\
\text { heat support and drinking hot water usage }\end{array}$ \\
\hline & Photovoltaic & Techn. System & $\begin{array}{l}\text { crystalline cells, horizontally mounted; } \\
\text { size of collector area }\left(\mathrm{A}_{\mathrm{PV}}\right)=\mathrm{A}_{\mathrm{SEU}}-\mathrm{A}_{\mathrm{SH}}\end{array}$ \\
\hline
\end{tabular}

\section{Results}

In order to fully credit the renewable energy sources generated by the building itself/on-site in the future, it would make sense to give a clear presentation of the power supply (input) and the feed-in (output) of the building. Therefore, a two-dimensional representation of the input-output balance is used in the discussion of the total building performance, since it allows the relationships between the energy inputs and outputs to be clarified.

When considering the overview of all of the data series of the ten case studies (Figure 5), differences between the individual results can be recognized. The greater the distance between the right data point (RB according to EnEV 2013) and the left data point (nZEB 2021) of a row, with respect to the $\mathrm{x}$-axis, the higher the absolute reduction of the $\mathrm{Q}^{\prime}{ }_{\mathrm{PNE}}(\Delta \mathrm{x})$. 


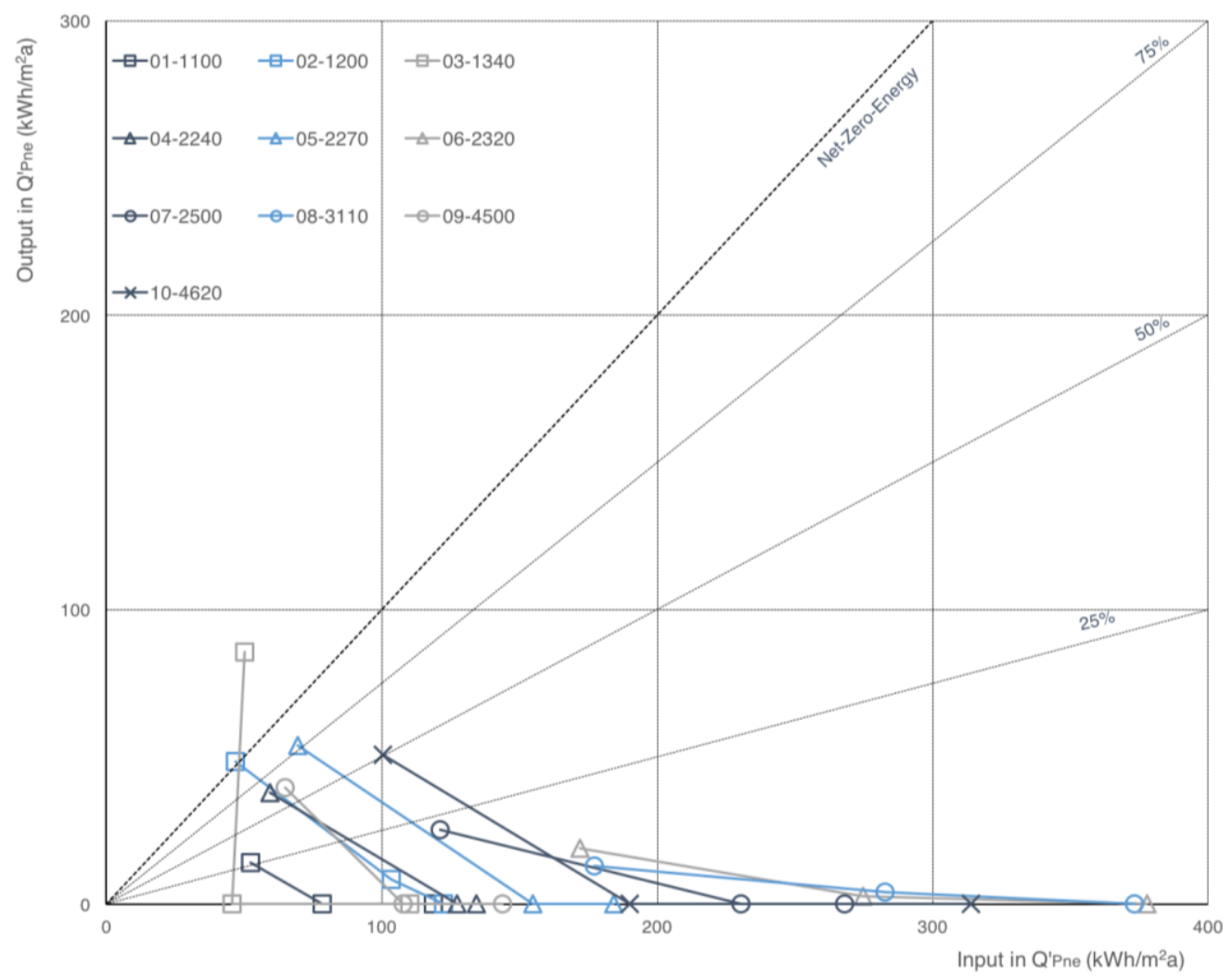

Figure 5. The results of all case studies-input-output balance ( $\left.\mathrm{Q}^{\prime} \mathrm{PNE}\left(\mathrm{kWh} / \mathrm{m}^{2} \mathrm{a}\right)\right)$ of the energy standard's reference building according to EnEV (right data point), standard case study (middle data point), and standard nZEB 2021 (left data point).

The highest absolute demand reductions in the $\mathrm{Q}^{\prime}{ }_{\mathrm{PNE}}$ tended to be achieved by the buildings whose reference design had a high demand (often buildings with a high degree of technical installation) and large volumes. The three best results were:

- $\quad 10-4620$ (museum building)

- $\quad 06-2320$ (research centre)

- $08-3110$ (hospital)

The lowest reduction was:

$$
\begin{aligned}
& \Delta \mathrm{x}=213.6 \mathrm{kWh} / \mathrm{m}^{2} \mathrm{a} \\
& \Delta \mathrm{x}=205.8 \mathrm{kWh} / \mathrm{m}^{2} \mathrm{a} \\
& \Delta \mathrm{x}=196.1 \mathrm{kWh} / \mathrm{m}^{2} \mathrm{a}
\end{aligned}
$$

- $\quad$ 03-1340 (office/administration building) $\quad \Delta \mathrm{x}=59.9 \mathrm{kWh} / \mathrm{m}^{2} \mathrm{a}$

The $y$-value indicates the grid feed (input). It should be noted that this is not the absolute power generation of the PV systems, but only the ratio of the grid feed to the generated electricity. The generated electricity is primarily used to reduce the energy consumption of the building itself and is deducted using the monthly balance sheet method. The best results are:

- $\quad 03-1340$ (police station)

- $\quad 05-2270$ (institute building)

- $\quad 10-4620$ (museum building)

- $\quad$ 02-1200 (courthouse)

$$
\begin{aligned}
& \mathrm{y}=85.8 \mathrm{kWh} / \mathrm{m}^{2} \mathrm{a} \\
& \mathrm{y}=54.0 \mathrm{kWh} / \mathrm{m}^{2} \mathrm{a} \\
& \mathrm{y}=50.9 \mathrm{kWh} / \mathrm{m}^{2} \mathrm{a} \\
& \mathrm{y}=48.6 \mathrm{kWh} / \mathrm{m}^{2} \mathrm{a}
\end{aligned}
$$

All of the case studies with good input results have a roofing plan that is well-suited for solar energy. Large flat surfaces without shading due to technical installations and roof structures are required. For example, they have no technical rooms on their roofs (e.g., for HVAC systems) that 
are built with an offset to the edge of the building due to design or zoning laws, which reduce the usable area. In addition, their buildings have between two and three usable floors (case study 10 has four storeys). Case study 03 also uses an auxiliary building for solar energy, which results in a comparatively high feed-in value.

When considering the input-output balance, three of the ten case studies do not reach the $25 \%$ coverage rate:

- 08-3110 (hospital)

- $\quad 06-2320$ (research centre)

- $\quad$ 07-2500 (laboratory building)

Seven buildings reach more than $25 \%$ :

- $\quad$ 01-1100 (parliament building)

Six buildings reach more than $50 \%$ :

- $\quad 10-4620$ (museum building)

- $\quad$ 09-4500 (library building)

- 04-2240 (university building)

Three buildings reach over $75 \%$ :

- $\quad$ 05-2270 (research building)
$7 \%$ coverage rate

$11 \%$ coverage rate

$21 \%$ coverage rate

$27 \%$ coverage rate

$51 \%$ coverage rate

$61 \%$ coverage rate

$64 \%$ coverage rate

Two buildings should be seen as net zero or net plus energy buildings:

- $\quad 02-1200$ (courthouse)

- $\quad$ 03-1300 (police station)

$104 \%$ coverage rate

$171 \%$ coverage rate

Under the assumptions of the study, it seems unrealistic to achieve a net zero-energy balance for all new buildings from 2021, as only two out of the ten case studies meet this standard.

Energy from renewable sources does not only affect the grid feed (output) in the balance sheet. Geothermal energy, solar thermal energy, and PV also reduce the non-renewable primary energy demand. The requirement of the EU directive is therefore fulfilled by combining the two parameters of non-renewable primary energy supply and the grid feed of renewable energies (two-dimensional balancing space, see point 7 ).

The relative specific primary energy demand of each building type is considered relative to the corresponding reference building $(=100 \%)$ (Figure 6$)$. This is the reference building method for the energy evaluation of new buildings, according to EnEV. This shows that all case studies use less than $55 \%$ of the demand of the reference buildings. The worst-case study here reaches $48 \%$. In three of the case studies, the production falls below $40 \%$ of the reference requirement (twice $32 \%$ and $38 \%$ ). The production of the majority of buildings is between $40 \%$ and $50 \%(44 \%-48 \%)$.

Since simplifications and generalizations were made in the analysis, the potential for reducing the demand and optimizing the energy generation of individual examples has not yet been exhausted. It is reasonable to expect that reaching a level of $40 \%$ of the specific primary energy demand (non-renewable) of the RB could even be exceeded without major effort, by including regional primary energy factors (for example district heating with cogeneration and waste incineration). Hopefully, this will not lead to a loss of building efficiency quality, in order to exploit the economic optimum. To address this issue, it is necessary to discuss which additional requirements should be placed on the specific primary energy demands (for example, a limitation on the delivered energy requirement according to [6]). 


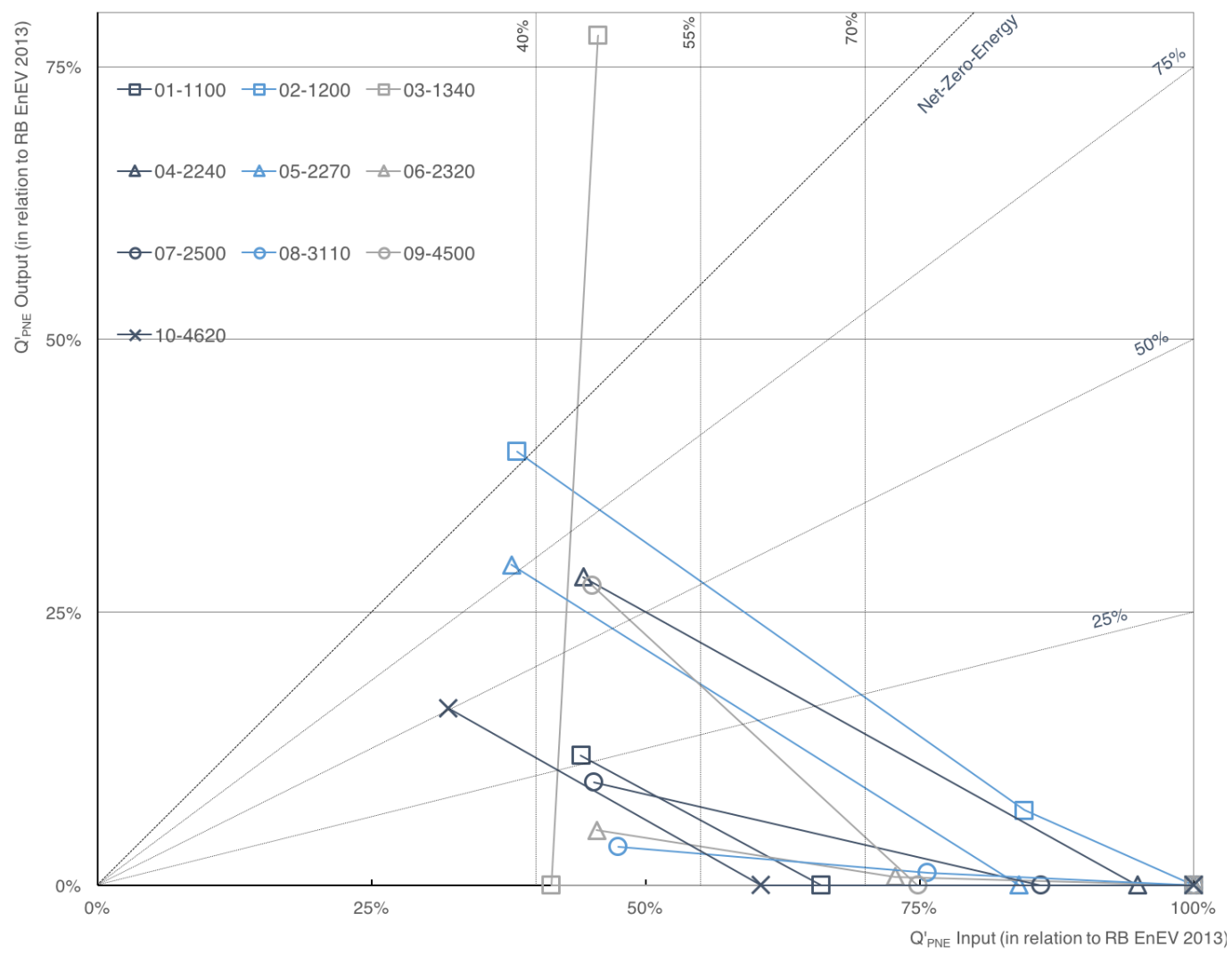

Figure 6. The result of all case studies-input-output balance $\left(Q^{\prime}{ }_{P N E}\left(k W h / m^{2} a\right)\right)$ as a percentage of the reference building (RB $2013=100 \%$ ) in the energy standard's reference building according to EnEV (right data point), standard case study (middle data point), and standard nZEB 2021 (left data point).

\section{Discussion}

\subsection{Target Area for a Nearly Zero Energy Standard 2021}

The discussion must be preceded by the fact that the number of case studies for general statements is too small. Regional specifications in the context of the case studies (e.g., regional primary energy factors) are neutralized by using general assumptions. But, there are still individual characteristics of the case studies that cannot be generalized. Nevertheless, it is an attempt to elaborate evidence for future investigations, which allows more accurate statements with other methods.

The results of this analysis can be used to propose a target range for a nZEB Standard for 2021. This proposal should consider the findings of state-of-the-art research and should also integrate the results of studies of different types of non-residential buildings. The following points are important:

- The one-dimensional view of energy demands, as currently stipulated by the EnEV, only allows energy-negative buildings to be balanced.

- $\quad$ The net balance of the energy supply (input) and grid export (output) is a survey that allows a transition from energy-negative to energy-positive buildings (two-dimensional target range).

- The self-consumption of renewable generated electricity greatly varies, depending on the building type. This affects the overall result of the input-output balance in the direction of the x-axis, as well as in the direction of the y-axis. Building types with high energy demands use their own consumption to reduce their demand, whereas building types with lower energy demands feed more energy into the grid.

It would therefore be useful to define the target area for nZEB in terms of these two parameters. The following represents an attempt to propose a draft requirement, based on the above analysis: One 
possible nZEB Standard can be established by defining a two-dimensional target area (nZEB 2021) in the input-output diagram (Figure 7), as follows. The permissible x-values (input non-renewable primary energy demand) are defined as $40 \%$ to $55 \%$ of the $\mathrm{RB}$, depending on the coverage of the output relative to the input. Forty percent was chosen as the lower threshold for the input, since it is an ambitious value for buildings with low feed-in (coverage $0 \%-25 \%$ ). This target is particularly accessible if more energy sources with high renewable shares are used (environmental heat, wood pellets, etc.) $[29,30]$.

One study even proposes that this standard should be the main requirement for the primary energy requirement of new buildings from 2021 onwards, for all building types, even without awarding credit for the potential grid feed [6].

A percentage of $55 \%$ of the $Q^{\prime}{ }_{P N E}$ requirement of the reference building is taken as the minimum standard for the input, since all building types in the above study far exceeded this value. Even critical building types with high degrees of installation and a high number of usable floors surpassed this standard. This criterion is thus chosen as the minimum efficiency standard, even for buildings that fall in the net plus energy range. This minimum standard guarantees that new buildings must achieve a minimum efficiency level. The principle that avoiding energy demand is preferable to regenerative cover, should also apply to future net plus energy houses [31]. Between the thresholds of $40 \%$ and $55 \%$ of the primary energy demand relative to the reference building, the requirement is uniformly graded in steps of $25 \%$, depending on the coverage ratio.

Buildings with input-output values located to the left of the requirement level (blue area) should be defined as nZEB. The proposed level of requirements is a snapshot for the year 2021. The requirement level will be evaluated and, if necessary, raised by a period of five years [1]. In 2050, a target range could be defined that is close to, or almost above, the net zero energy line.

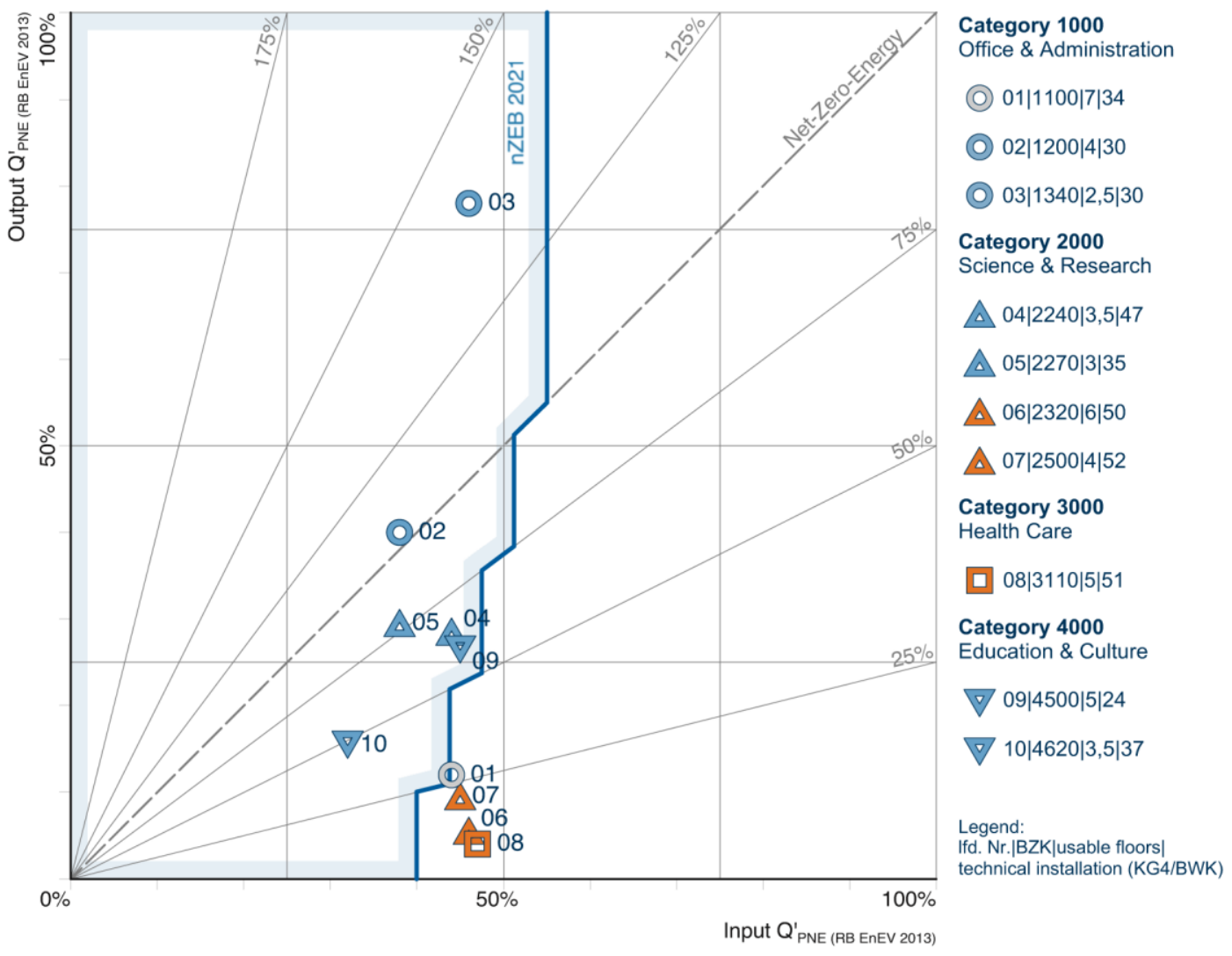

Figure 7. Input-output balance $\left(\mathrm{Q}^{\prime}{ }_{\mathrm{PNE}}\right)$ relative to reference building $(\mathrm{RB}=100 \%)$-Summary of case studies for standard nZEB 2021. 
If this definition is applied to the results of all ten case studies, seven out of ten would reach this level. Case studies 04 and 09 do not reach the $40 \%$ limit, but compensate for the higher energy demand by means of grid feed. It is thus possible to compensate, in part, for the energy demand by producing renewable energy. This approach is more open to technological innovation in new buildings from 2021 onward. In the case of larger renovations of buildings, this type of balancing allows the lower efficiency potential of existing buildings to be compensated, by producing energy within the building.

The three projects $(06,07$, and 08$)$ that do not achieve this nZEB level all have of a very high percentage of KG4/BWK, at over $50 \%$, and have four or more usable floors. Under the assumptions of the study, the production of renewable energy is strongly dependent on the available roof area for solar energy use. Buildings with several usable floors have limited proportions of usable roof area per square meter of the total floor area. In addition, buildings with a high percentage of KG4/BWK have the problem that the roof areas are regularly occupied by technical installations, which also reduces the roof area for solar use.

\subsection{Risk Assessment for the Property Portfolio of the Free State of Bavaria}

Due to the assumed unique standard for nZEB, variables of the case studies are reduced to design variables (geometry, A/V ratio, percentage window area, GFA, and GBV, height), usage variables (usage zoning, indoor air conditioning, lightning, and domestic hot water), and variables for solar energy use (roof area, relation between solar thermal and photovoltaic energy). The assessment is determined by the availability of data of the state-related properties (FDH). Since it does not include all of these variables, simplifications must be made. Assuming that a high efficient standard for the building envelope reduces the heat transfer losses to a minimum, and that every type of building has a specific geometry, the design variables are omitted for the assessment. For the main usage of the building, the four-digit code of the BZK is taken. The BZK code is an indicator of the building's energy demand, calculated by [12]. It provides additional information on the average technical construction costs as a ratio of KG4/BWK. As shown in Tables 1 and 3, the ratio of KG4/BWK is an indicator for the grade of technical installation that influences the available roof area for solar energy use. The potential for solar energy use is determined by the correlation between $\mathrm{A}_{\mathrm{SEU}}$ and the GFA. The only rough indicator available in the database for this correlation is the number of usable floors. The thresholds of these indicators were derived from the results of the study (Figures 5-7). By taking the building use, the degree of technical installation (KG4/BWK), and the number of usable floors as criteria for assessing the criticality of the building portfolio of Bavaria, an empirical assessment of the number of critical buildings can be made. Neither the selection of the criteria nor the evaluation fulfil the scientific standards of a statistical study. Nevertheless, this estimate is an indicator of the number of possible new buildings from 2021 onwards that will not be able to achieve the proposed performance requirements.

By considering the number of buildings of each type as a reference for building activity, an estimate can be established for the number of new buildings from 2021 that can be regarded as challenging and critical, with respect to the proposed nZEB Standard. This approach requires a consistent life span for all types of buildings and their replacement by equivalent new buildings.

Based on the case studies, boundaries were drawn for uncritical attributes $(+)$, attributes requiring individual case evaluations ( 0 ), and critical attributes (-), in order to determine the number of buildings in each of these categories. The results from Table 5 are shown in Figure 8.

Figure 8 shows the results: According to this evaluation, $86.8 \%$ of the new buildings from 2021 onwards can be considered as uncritical and implementable, with regard to the above-mentioned nZEB Standard 2021. A total of $8.4 \%$ of new buildings can be considered challenging, and $2.3 \%$ critical or very critical. This also includes all three case studies $(06,07$, and 08$)$ that did not reach the defined minimum energy standard. 
Table 5. Data analysis (number of buildings) of the property portfolio of Bavaria (data from [10]) using the criteria degree of technical installation (KG4/BWK) (data from $[15,16]$ ) and the number of usable (above-ground) floors, differentiated into uncritical (+), neutral (0), and critical (-) attributes.

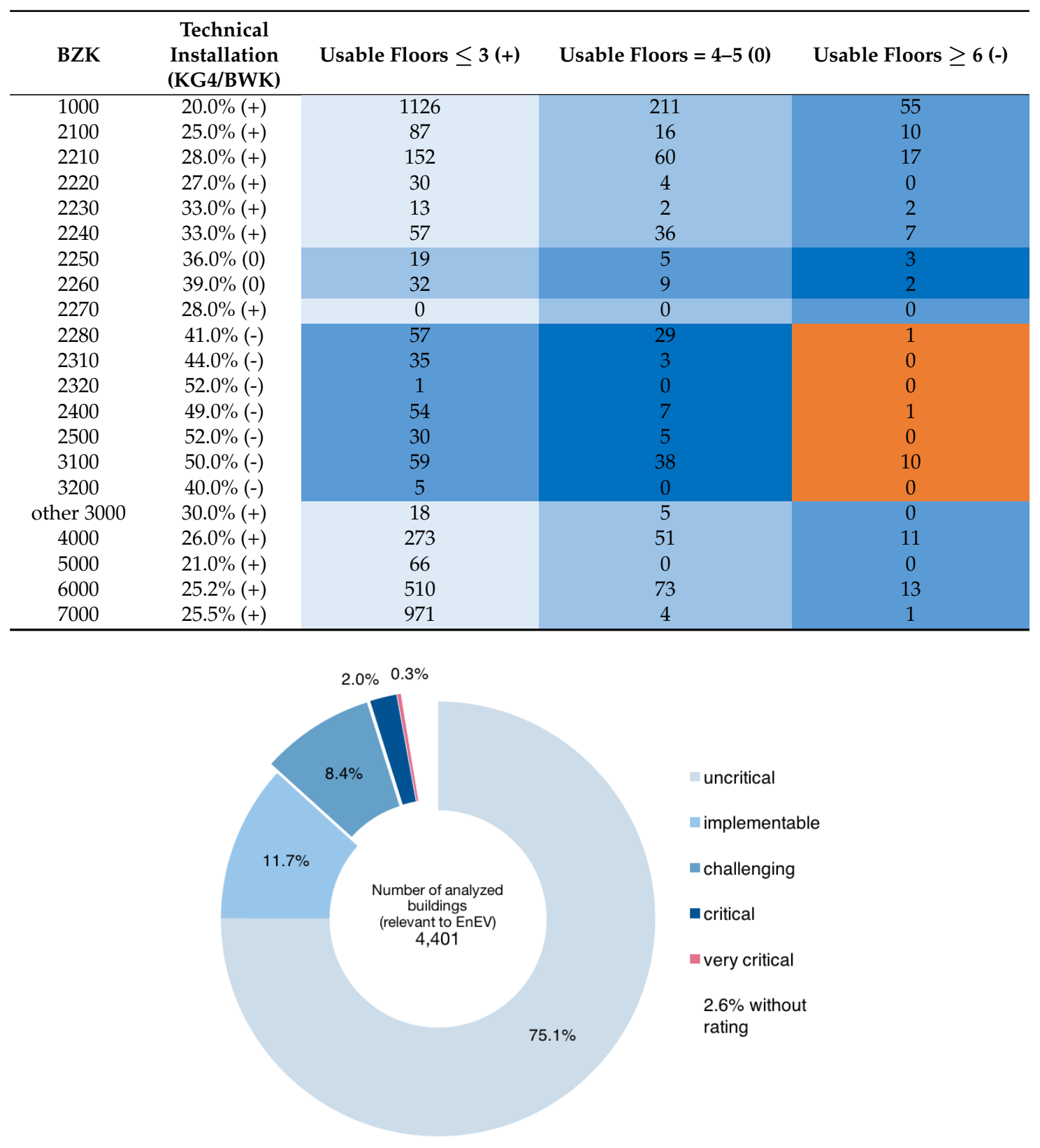

Figure 8. Risk assessment with the criteria of degree of technical installation (KG4/BWK) and usable (above ground) floors using the example of the FDH of Bavaria [10].

\section{Conclusions}

By 2050, the building stock should be almost climate-neutral [5]. At this point in time, most new buildings (including completely refurbished buildings) built after 2021 will still be in operation [32]. They have to meet the requirement for climate-neutral operation as early as 2021. If the energy performance of the buildings standard for 2021 is defined in such a way that all building types can achieve it, much of the potential for climate protection would be left unused, due to the few types of critical buildings (Figure 8). This "lowest common denominator" approach certainly does not lead towards achieving the goal by 2050. Instead of this approach, the authors suggest an individualization 
of energy concepts for non-residential buildings with high energy demands. For the majority of new buildings, the building regulations stipulate general rules that can be used to achieve and demonstrate compliance with the protection objective. For special types of buildings, whose usage and complexity requires special measures beyond the general rules, an expert elaborates an individualized concept for energy usage and climate protection. If this approach would be applied to the energy verification process in Germany, the upcoming EnEV regulations could cover the majority of new buildings. The energy performance of new buildings with critical attributes would be calculated by specialist designers, according to a fixed list of criteria. In this case, the protection target definitions would have to be established based on the climate protection goals.

A climate-neutral building stock has so far been defined by using the operating energies [1]. However, the total energy consumption in the building sector is composed of construction, operating, and demolition energies. The lower the percentage of the operating energy, the higher the percentage of the embodied energy of a building. Even after achieving the standards nZEB and ZEB, we are not yet done. Our next goal should be to achieve a life cycle zero energy building (LC-ZEB), as shown in $[33,34]$.

Acknowledgments: This work was supported by the German Research Foundation (DFG) and the Technical University of Munich (TUM) in the framework of the Open Access Publishing Program. Thanks to the Bavarian Ministry of the Interior, for Building and Transport, for providing the anonymized data on the state-related properties. Special thanks to John Anderson for the proofreading of the English grammar and to the two anonymous reviewers and the academic editor for their comments.

Author Contributions: The study was performed and written by Michael Keltsch. Werner Lang and Thomas Auer are the academic supervisors.

Conflicts of Interest: The authors declare no conflict of interest.

\section{References}

1. European Union. Directive 2010/31/EU of the European Parliament and the Council of 19 May 2010 on the Energy Performance of Buildings (Recast) (L153/13-35); European Union: Brussels, Belgium, 2010.

2. Roberto, G.; Vallentin, R. Passive House Design: Planning and Design of Energy-Efficient Buildings; Detail, Institut für Internationale Architektur-Dokumentation: Munich, Germany, 2014.

3. Voss, K.; Musall, E. Net Zero Energy Buildings-International Projects of Carbon Neutrality in Buildings, 2nd ed.; Detail, Institut für Internationale Architektur-Dokumentation: Berlin, Germany, 2012; ISBN: 978-3-920034-80-5.

4. Statistisches Bundesamt. Statistisches Jahrbuch 2014; Statistisches Bundesamt: Wiesbaden, Germany, 2014.

5. Erhorn, H.; Bermann, A. Wege zum Effizienzhaus Plus; Bundesministerium für Umwelt, Naturschutz, Bau und Reaktorsicherheit: Berlin, Germany, 2014.

6. Bundesministerium für Verkehr Bau und Stadtentwicklung (Hrsg.). Untersuchung zur Novellierung der EU-Gebäudenergieeffizienzrichtlinie (EPBD); Identifikation und Analyse von Hemmnissen beim Neubau von Hocheffizienten (Niedrigstenergie-)Gebäuden und Entwicklung eines Konzepts zur Marktdurchdringung bis 2020: Berlin, Germany, 2012.

7. German Federal Government. Energieeinsparverordnung vom 24. Juli 2007 (BGBl. I S. 1519), die durch Artikel 326 der Verordnung vom 31. August 2015 (BGBl. I S. 1474) geändert worden ist. Available online: https:/ / www.gesetze-im-internet.de/enev_2007/ (accessed on 21 December 2016).

8. Passig, I.; Hegger, M.; Fafflok, C.; Hegger, J. Aktivhaus_-The Reference Work: From Passivhaus to Energy-Plus House; Birkhauser: Basel, Switzerland, 2016.

9. Oberste Baubehörde im Bayerischen Staatsministerium des Innern, für Bau und Verkehr. Jahresbericht der Staatsbauverwaltung 2014; Oberste Baubehörde im Bayerischen Staatsministerium des Innern, für Bau und Verkehr: Munich, Germany, 2015.

10. Oberste Baubehörde im Bayerischen Staatsministerium des Innern, für Bau und Verkehr. Fachdatenbank Hochbau; Stand 21.04.2015; Oberste Baubehörde im Bayerischen Staatsministerium des Innern, für Bau und Verkehr: Munich, Germany, 2014. 
11. Bauministerkonferenz (ARGEBAU). Bauwerkzuordnungskatalog. Available online: https://www. bauministerkonferenz.de/verzeichnis.aspx?id=1356\&o=5107 (accessed on 15 June 2015).

12. DIN V 18599:2016-12. Energetische Bewertung von Gebäuden-Berechnung des Nutz-, End- und Primärenergiebedarfs für Heizung, Kühlung, Lüftung, Trinkwarmwasser und Beleuchtung (Normenreihe Vornorm), Beuth: Berlin, Germany, 2016.

13. Leibniz-Institut für ökologische Raumentwicklung; Ingenieurbüro Ralph Petereit. Typologie und Bestand beheizter Nichtwohngebäude in Deutschland; BMVBS-Online-Publikation 2010. Available online: http:/ / www.bbsr.bund.de/BBSR/DE/Veroeffentlichungen/BMVBS/Online/2011/DL_ON162011. pdf;jsessionid=C41CFE29EBDB87F3E589C355A55BEA70.live11291?_blob=publicationFile\&v=2 (accessed on 15 June 2016).

14. DIN 276-1:2008-12. Building Costs_Part 1: Building Construction, Beuth: Berlin, Germany, 2008.

15. Baukosteninformationszentrum Deutscher Architektenkammern. BKI Baukosten 2016 Neubau; Baukosteninformationszentrum Deutscher Architektenkammern: Stuttgart, Germany, 2016.

16. Bauministerkonferenz (ARGEBAU). Kostenrichtwerte für Hochschulgebäude. Available online: https: / / www.bauministerkonferenz.de/verzeichnis.aspx?id=1356\&o=512005107 (accessed on 6 April 2015).

17. Peel, M.C.; Finlayson, B.L.; Mcmahon, T.A. Updated world map of the Köppen-Geiger climate classification. In Hydrology and Earth System Sciences Discussions; European Geosciences Union: Munich, Germany, 2007; Volume 4, pp. 439-473.

18. Sartori, I.; Napolitano, A.; Voss, K. Net zero energy buildings: A consistent definition framework. Energy Build. 2012, 48, 220-232. [CrossRef]

19. Marszal, A.J.; Heiselberg, P.; Bourrelle, J.S.; Musall, E.; Voss, K.; Sartori, I.; Napolitano, A. Zero energy building-A review of definitions and calculation methodologies. Energy Build. 2011, 43, 971-979. [CrossRef]

20. Marszal, A.J.; Bourrelle, J.S.; Musall, E.; Heiselberg, P.; Gustavsen, A.; Voss, K. Net Zero Energy Buildings-Calculation Methodologies versus National Building Codes. In Proceedings of the EuroSun Conference, Graz, Austria, 28 September-1 October 2010.

21. Federal Institute for Research on Building, Urban Affairs and Spatial Development (Ed.) Marktuntersuchung und Evaluierung zum Energieausweis-System für Nichtwohngebäude und Entwicklung Geeigneter Vereinfachungen für die Energieausweiserstellung; BMVBS-Online-Publikation 09/2012. Available online: http:/ /www.bbsr. bund.de/BBSR/DE/Veroeffentlichungen/BMVBS/Online/2012/ON092012.html?nn=396116 (accessed on 6 April 2016).

22. Lichtmeß, M. EnerCalC, vereinfachte Energiebilanzen nach DIN V 18599. Available online: http:/ / www. enob.info/?id=enercalc (accessed on 15 June 2015).

23. Lichtmeß, M. Vereinfachungen für die Energetische Bewertung von Gebäuden. Ph.D. Thesis, Bergische Universität Wuppertal, Fachbereich D-Architektur, Wuppertal, Germany, 2010.

24. Lüking, R.-M.; Hauser, G. Die thermische Konditionierung von Gebäuden im Kontext eines zukünftigen Energieversorgungssystems: Studie des Fraunhofer-instituts für Bauphysik; Fraunhofer-IRB-Verl.: Stuttgart, Germany, 2011.

25. Rodriguez-Urbinas, E.; Rodriguez, S.; Voss, K.; Todorovic, M. Energy efficiency evaluation of zero energy houses. Energy Build. 2014, 83, 23-35. [CrossRef]

26. Beuth Hochschule; ifeu Institut. Dämmbarkeit des Deutschen Gebäudebestandes; Beuth Hochschule: Berlin, Germany, 2015.

27. Prognos; Ifeu; IWU. Hintergrundpapier zur Energieeffizienzstrategie Gebäude-Erstellt im Rahmen der Wissenschaftlichen Begleitforschung zur Erarbeitung einer Energieeffizienzstrategie Gebäude; Prognos: Berlin/Heidelberg/Darmstadt, Gemany, 2015.

28. Quaschning, V. Systemtechnik einer klimaverträglichen Elektrizitätsversorgung in Deutschland für das 21. Jahrhundert; VDI-Verl.: Düsseldorf, Germany, 2000.

29. Visa, I.; Moldovan, M.D.; Comsit, M.; Duta, A. Improving the renewable energy mix in a building toward the nearly zero energy status. Energy Build. 2014, 68, 72-78. [CrossRef]

30. Pless, S.D.; Torcellini, P.A. Net-Zero Energy Buildings: A Classification system Based on Renewable Energy Supply Options; National Renewable Energy Laboratory: Golden, CO, USA, 2010.

31. Lüking, R.-M.; Hauser, G. Plusenergiehäuser: Technische und Ökonomische Grundlagen; Fraunhofer Verl.: Stuttgart, Germany, 2012. 
32. Nemeth, I.; Lindauer, M. Adaptation of a stochastic simulation model for long-term investigation of the development of the energy demand in larger building stocks. In Proceedings of the International Workshop: Intelligent Computing in Engineering, Munich, Germany, 4-6 July 2012.

33. Hernandez, P.; Kenny, P. From net energy to zero energy buildings: Defining life cycle zero energy buildings (lc-zeb). Energy Build. 2010, 42, 815-821. [CrossRef]

34. Schneider, P.; Lang, W. Architecture and technology-A life cycle assessment perspective on self-sufficient buildings. In Proceedings of the PLEA 2015, 31th International PLEA Conference, Bologna, Italy, 9-11 September 2015.

(c) (9)

(C) 2017 by the authors. Licensee MDPI, Basel, Switzerland. This article is an open access article distributed under the terms and conditions of the Creative Commons Attribution (CC BY) license (http:/ / creativecommons.org/licenses/by/4.0/). 